\title{
Penerapan pendekatan saintifik dilengkapi LKS pada mata pelajaran Geografi untuk meningkatkan kemampuan berpikir analitis siswa kelas XI IPS 2 SMAN 8 Malang
}

\author{
Purwa Sasmita Rahayu, Budi Handoyo*, Hendri Purwito \\ Universitas Negeri Malang, Jl. Semarang No. 5 Malang, Jawa Timur, Indonesia \\ *Penulis korespondensi, Surel: budi.handoyo.fis@um.ac.id
}

Paper received: 02-03-2021; revised: 15-03-2021; accepted: 30-03-2021

\begin{abstract}
The ability of analytical thinking is one of the cognitive aspects that must be mastered by students. Pre-research observation results conducted in Class XI IPS 2, SMAN 8 Malang There were about 22 students from 35 students who scored below the average or around 62.9 percent. the data confirms that there are some students who still cannot solve the type C4 (Analysis) questions. Based on the research that has been done, it can be obtained that 1) there is an increase in students' analytical thinking skills in cycles I and II, 2) The application of the Scientific Approach with LKS is proven to be able to improve the student's analytical thingking in class XI IPS 2, SMAN 8 Malang.
\end{abstract}

Keywords: scientific approach; LKS; analytical thinking ability

\begin{abstract}
Abstrak
Kemampuan berpikir analitis merupakan salah satu aspek kognitif yang harus dikuasai oleh siswa. Hasil observasi pra penelitian yang dilakukan di Kelas XI IPS 2, SMA Negeri 8 Malang Terdapat sekitar 22 siswa dari 35 siswa yang mendapat nilai di bawah rata- rata atau sekitar 62.9 persen. data tersebut memperkuat bahwa terdapat beberapa siswa yang masih belum dapat menyelesaikan soal tipe C4 (Analisis). Berdasarkan penelitian yaang telah dilakuan didapatkan hasil 1) adanya peningkatan kemampuan berpikir analitis siswa pada siklus I dan II 2) Penerapan Pendekatan Saintifik dilengkapi LKS terbukti mampu meningkatkan kemampuan berpikir analitis siswa kelas XI IPS 2 SMAN 8 Malang.
\end{abstract}

Kata kunci: pendekatan saintifik; LKS; kemampuan berpikir analitis

\section{Pendahuluan}

Berpikir analitis sangat diperlukan bagi siswa dalam menerima dan memahami suatu materi pelajaran. Kemampuan berpikir analitis sangat penting bagi siswa karena dalam aspek ini siswa dapat memanfaatkan unsur dari pengetahuan, pemahaman dan juga aplikasi (Jurnal Penabur, 2012; M.Taleb \& Chadwick, 2016; Robbins, 2011). Menjawab berbagai macam soal baik itu esay maupun pilihan ganda, siswa di tuntut untuk dapat memilih jawaban yang paling benar. Kemampuan dalam memilih jawaban dengan benar ini merupakan aspek dari berpikir analitis. Pada Abad ke-21 kemampuan berpikir analitis masih belum dikuasi oleh siswa.

Salah satu sekolah di Kota Malang yakni SMA Negeri 8 Malang, juga mengalami permasalahan yang sama dalam kemampuan berpikir analitis siswanya. Setelah di lakukan observasi Prasiklus pada kelas XI IPS 2 untuk mengerjakan soal pada mata pelajaran geografi dengan tipe soal C4 (Analisis). Hasil dari penyelesaian soal tersebut yakni hanya 13 dari 35 siswa yang hampir dapat menjawab sesuai dan mendapat nilai di atas rata- rata. Dapat dikatakan $37,1 \%$ dari jumlah siswa di kelas mendapat nilai diatas rata- rata. Terdapat sekitar 22 siswa dari 35 siswa yang mendapat nilai di bawah rata- rata atau sekitar 62,9\%. Data 
tersebut memperkuat bahwa terdapat beberapa siswa yang masih belum dapat menyelesaikan soal tipe C4 (Analisis). Data tersebut menjadi fakta bahwa perlu adanya tindakan untuk siswa agar dapat meningkatkan kemampuan berpikir analitis di SMAN 8 Malang. Setelah dilakukan observasi prasiklus kemampuan berpikir analitis siswa di Kelas XI IPS 2 dipengaruhi oleh beberapa faktor yakni pendekatan yang dilakukan di dalam kelas masih belum sesuai dengan kurikulum yang berjalan saat ini dan belum terdapat media yang tepat untuk memberikan penugasan pada siswa. Kedua permasalahan tersebut merupakan permasalahan utama atau faktor penyebab kurangnya kemampuan berpikir analitis yang terjadi di SMAN 8 Malang.

Pendekatan siantifik dalam pembelajaran telah banyak diteliti dan menghasilkan hasil positif dalam meningkatkan baik hasil belajar maupun kemampuan berpikir kreatif. Akan tetapi penelitian mengenai pendekatan saintifik untuk meningkatkan kamampuan berpikir analitis masih jarang ditemui. LKS sebagai tambahan dalam pendekatan saintifik akan mempermudah peneliti dalam meningkatkan kemampuan berpikir analitis siswa, oleh karena itu penelitian dalam penerapan pendekatan saintifik dengan media LKS dalam meningkatkan kemampuan berpikir analitis siswa sangat perlu dilakukan.

\section{Metode}

Tujuan penelitian ini untuk mengetahui peningkatan kemampuan berpikir analitis siswa kelas XI IPS 2, SMAN 8 Malang pada materi jenis dan penanggulangan bencana alam melalui edukasi, kearifan lokal, dan pemanfaatan teknologi modern dengan menerapkan pendekatan saintifik dilengkapi dengan LKS.Rancangan yang digunakan dalam penelitian ini adalah Penelitian Tindakan Kelas (PTK) dengan langkah penelitian yakni perencanaan, pelaksanaan, pengamatan dan refleksi. Penelitian ini dilakukan dalam dua kali siklus penelitian. subjek penelitian ini adalah siswa kelas XI IPS 2 dengan jumalah 34 siswa di SMAN 8 Malang pada mata pelajaran geografi.

Instrument Penelitian yang akan digunakan adalah soal tes. Soal yang diberikan berdasarkan materi yang disampaikan sesuai denga bahan ajar geografi kelas XI IPS 2 di SMAN 8 Malang dan sesuai pada KI dan KD yang berjalan dikelas tersebut saat terjadi penelitian. Soal tes yang akan diberikan berupa soal esai yang terdiri atas 5 butir soal pada masing- masing siklus. Tes yang dilakukan bertujuan untuk mengetahui kemampuan berpikir analitis siswa dan diberikan setelah pemberian tindakan pada siklus I, II dan seterusnya menggunakan pendekatan saintifik.

\section{Hasil dan Pembahasan}

Paparan data pelaksanaan tindakan berisi mengenai hasil temuan penelitian yang telah dilakukan peneliti dalam beberapa siklus. selain terdapat pemaparan data yang telah ditemukan, peneliti akan menjelaskan pelaksanakan tindakan pada saat melakukan penelitian dengan menggunakan pendekatan saintifik dilengkapi LKS pada mata pelajaran geografi di SMA Negeri 8 Malang. Penelitian yang dilakuikan sesuai dengan langkah-langkah PTK (Penelitian Tindakan Kelas) yang terdiri dari tiga tahap yakni: 1) Tahap Pra Tindakan 2) Tahap Pelaksanaan Tindakan Siklus I 3) Tahap Pelaksanaan Siklus II. Setiap siklus memiliki langkahlangkah yaitu, perencanaan, pelaksanaan, pengamatan dan refleksi. Data penelitian didapatkn dari nilai tes yang dikerjakan oleh siswa dari soal tes kemampuan berpikir analitis. 


\subsection{Data Kemampuan Berpikir Analisis Pada Siklus I}

Tabel 1. Distribusi Frekuensi Nilai Kemampuan Berpikir Analitis Siklus I

\begin{tabular}{lllll}
\hline Klasifikasi & Nilai & Kualifikasi & Frekuensi & Presentase \\
\hline A & $80-100$ & Sangat baik & 15 & $68.18 \%$ \\
B & $66-79$ & Baik & 0 & $0 \%$ \\
C & $56-65$ & Cukup & 4 & $18.18 \%$ \\
D & $40-55$ & Kurang & 2 & $9.09 \%$ \\
E & $0-39$ & Sangat Kurang & 1 & $4.55 \%$ \\
& Jumlah & & 22 & $100 \%$ \\
\hline
\end{tabular}

Pada tabel 1 menunjukkan bahwa pada siklus I kemampuan berpikir analitis siswa sudah membaik dibandingkan dengan prasiklus dengan persentasi tidak lebih dari $50 \%$. Namun setelah diberikan tindakan pada siklus I maka sudah lebih dari 50\% siswa telah memperlihatkan peningkatan dalam kemampuan berpikir analitisnya atau $68.18 \%$ siswa. Siswa yang memiliki kualifikasi nilai sangat baik berjumlah 15 siswa atau $68.18 \%$ dari jumlah total siswa. Siswa yang memiliki kualifikasi nilai baik dengan persentase $0 \%$ dengan jumlah 0 dari total siswa keseluruhan. Siswa yang memiliki kualifikasi nilai cukup berjumlah 4 orang siswa atau $18.18 \%$ dari jumlah total siswa. Siswa yang miliki kualifikasi nilai kurang berjumlah 2 siswa atau 9.09\% dari jumlah total siswa. Siswa yang memiliki kualifikasi nilai sangat kurang berjumlah 1 atau $4.55 \%$ dari jumlah siswa keseluruhan. Berikut perbandingan dari hasil kelima kualifikasi pada siklus I yang akan disajikan dalam grafik berikut:

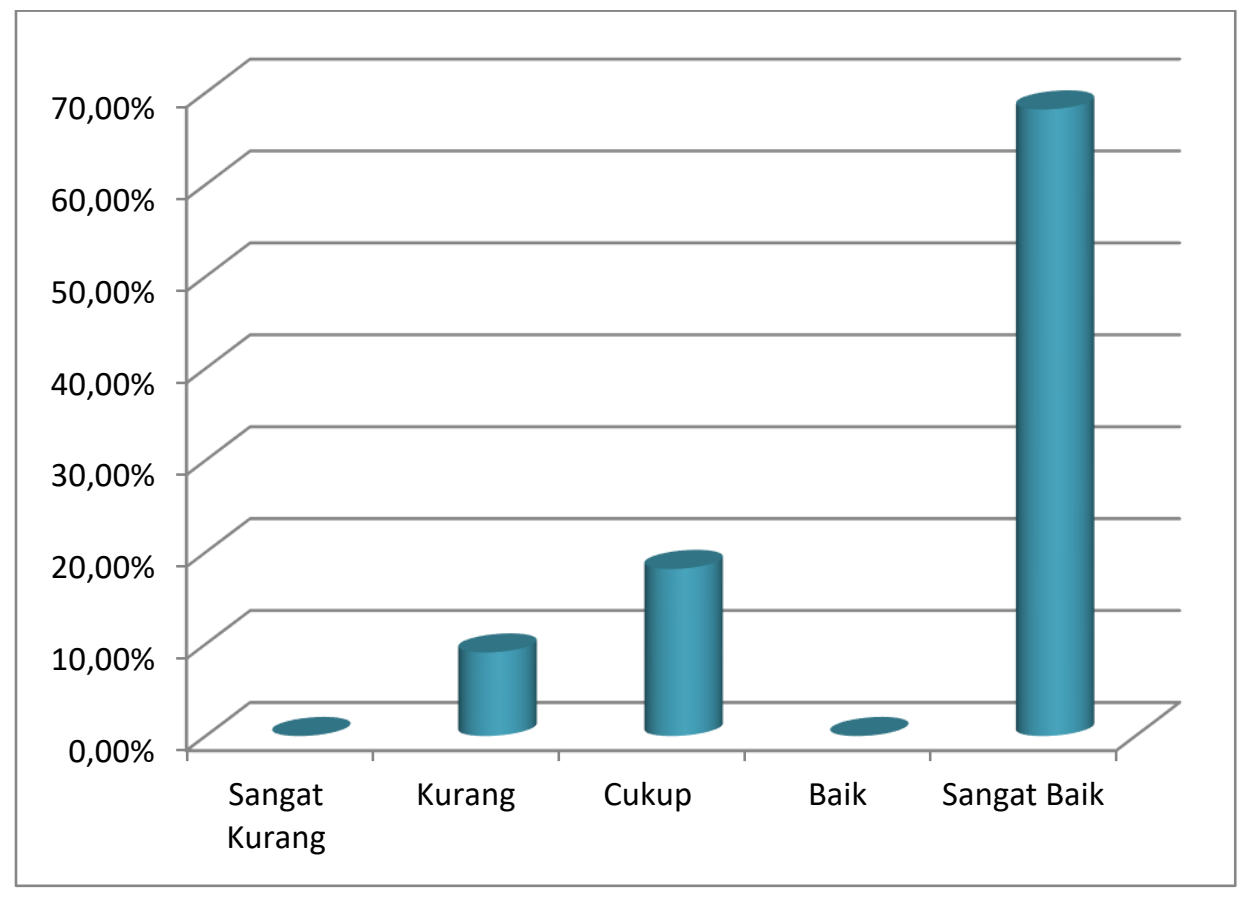

Gambar 1. Grafik Kemampuan Berpikir Analitis Siswa Siklus I

Gambar 1. menunjukkan bahwa 15 dari total 22 siswa mendapatkan nilai sangat baik. Sedangkan pada klasifikasi baik tidak terdapat siswa yang mendapatkan nilai tersebut, 4 siswa mendapatkan nilai cukup, 2 siswa mendapatkan nilai kurang, dan 1 siswa mendapatkan nilai sangat kurang. 


\subsection{Data Kemampuan Berpikir Analisis Pada Siklus II}

Tabel 2. Distribusi Frekuensi Nilai Kemampuan Berpikir Analitis Siklus II

\begin{tabular}{lllll}
\hline Klasifikasi & Nilai & Kualifikasi & Frekuensi & Presentase \\
\hline A & $80-100$ & Sangat baik & 23 & $79.31 \%$ \\
B & $66-79$ & Baik & 1 & $3.44 \%$ \\
C & $56-65$ & Cukup & 3 & $10.34 \%$ \\
D & $40-55$ & Kurang & 0 & $0 \%$ \\
E & $0-39$ & Sangat Kurang & 2 & $6.91 \%$ \\
& Jumlah & & 29 & $100 \%$ \\
\hline
\end{tabular}

Pada tabel 4.2 menunjukkan bahwa pada siklus II kemampuan berpikir analitis siswa sudah membaik dibandingkan dengan siklus I dimana pada siklus I kemampuan berpikir analitis siswa mencapai $68.18 \%$. Pada siklus II memperlihatkan peningkatan dalam kemampuan berpikir analitisnya yakni $79.31 \%$ siswa. Siswa yang memiliki kualifikasi nilai sangat baik berjumlah 23 siswa dari 29 siswa atau 79.31\% dari jumlah total siswa. Siswa yang memiliki kualifikasi nilai baik dengan persentase 3.44\% dengan jumlah 1 dari total siswa keseluruhan. Siswa yang memiliki kualifikasi nilai cukup berjumlah 3 orang siswa atau $10.34 \%$ dari jumlah total siswa. Siswa yang miliki kualifikasi nilai kurang berjumlah 0 siswa atau $0 \%$ dari jumlah total siswa. siswa yang memiliki kualifikasi nilai sangat kurang berjumlah 2 atau 6.91\% dari jumlah siswa keseluruhan. Berikut perbandingan dari hasil kelima kualifikasi pada siklus I yang akan disajikan dalam grafik berikut:

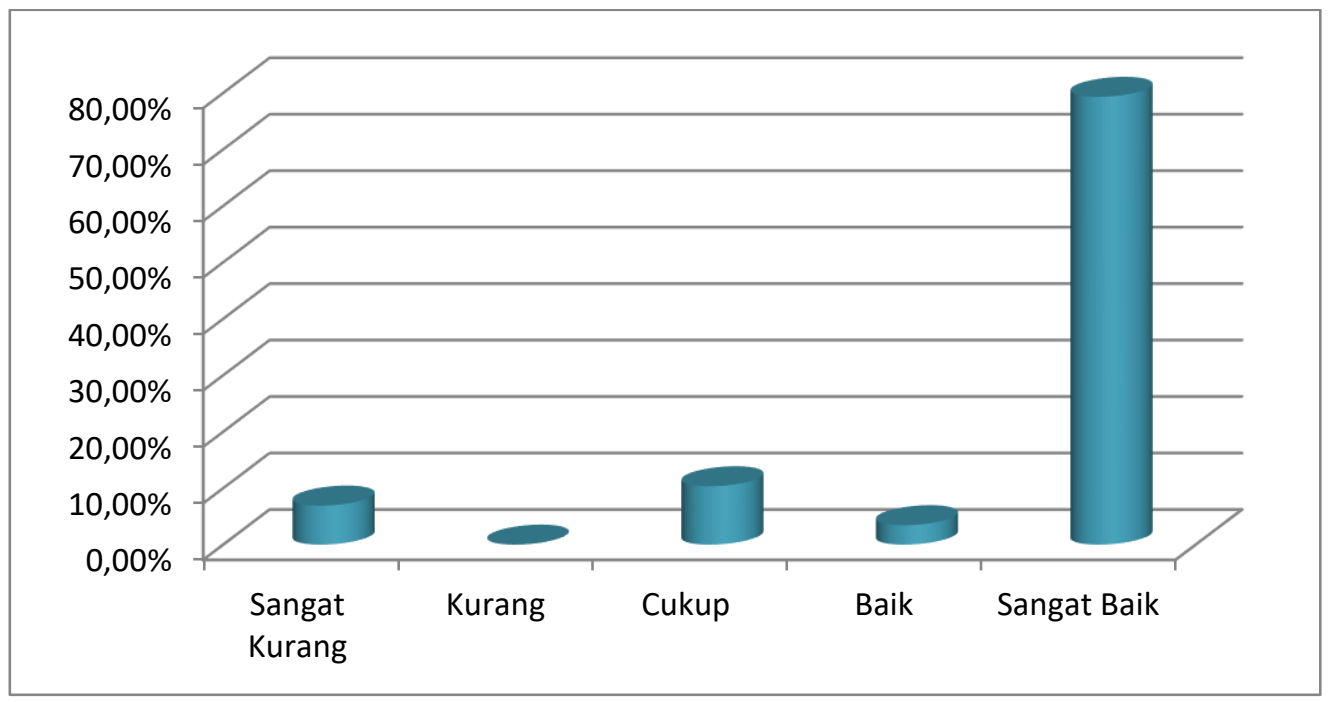

Gambar 2. Grafik Kemampuan Berpikir Analitis Siswa Siklus II

Grafik 2 menunjukkkan bahwa 23 dari total 29 siswa mendapatkan nilai sangat baik di kelas XI IPS 2 dengan nilai tertinggi yakni 90. Sedangkan pada klasifikasi baik terdapat 1 siswa dengan nilai tertinggi yakni 70. Pada klasifikasi cukup terdapat 3 siswa dengan nilai tertinggi yakni 60. Tidak terdapat siswa pada klasifikasi kurang, akan tetapi terdapat 2 siswa yang memiliki klasifikasi nilai sangat kurang dengan nilai tertinggi yakni 30.

\subsection{Analisis Data}

Analisis data kemampuan berpikir analitis siswa dilakukan untuk mengetahui perbandigan nilai rata-rata kemampuan berpikir analitis siswa. hal ini bertujuan untuk 
membuktikan apakah ada peningkatan kemampuan berpikir analitis siswa dari rata-rata total nilai siswa siklus I dan siklus II. Analisis data juga dapat membrikan informasi mengenai keberhasilan penerapan pendekatan siantifik dilengkapi LKS. Perbandiang perolehan nilai rata-rata kemampuan berpikir analitis siswa disajikan dalam tabel sebagai berikut:

Tabel 3. Perbandingan Perolehan Nilai Rata-Rata Kemampuan Berpikir Analitis Siswa siklus I ke Siklus II

\begin{tabular}{llll}
\hline Siklus & $\begin{array}{l}\text { Rata-Rata Nilai Kemampuan } \\
\text { Berpikir Siswa }\end{array}$ & Peningkatan & $\begin{array}{l}\text { Presentase } \\
\text { Peningkatan }\end{array}$ \\
\hline Siklus I & 70 & - & \\
Siklus II & 76.55 & 6.55 & $9.36 \%$ \\
\hline
\end{tabular}

Tabel 3. menunjukkan bahwa nilai rata-rata nilai kemampuan berpikir analitis siswa siklus I adalah 70 dengan kualifikasi baik, sedangkan nilai rata-rata nilai kemampuan berpikir analitis siswa siklus II adalah 76.55 dengan kualifikasi baik. Dengan demikian perhitungan selisih rata-rata dari siklus I ke siklus II adalah 6.55. persentase peningkatan kemampuan berpikir analitis siswa dari siklus I ke siklus II sebesar 9.36\%. Berikut yakni grafik peningkatan kemampuan berpikir analitis siswa.

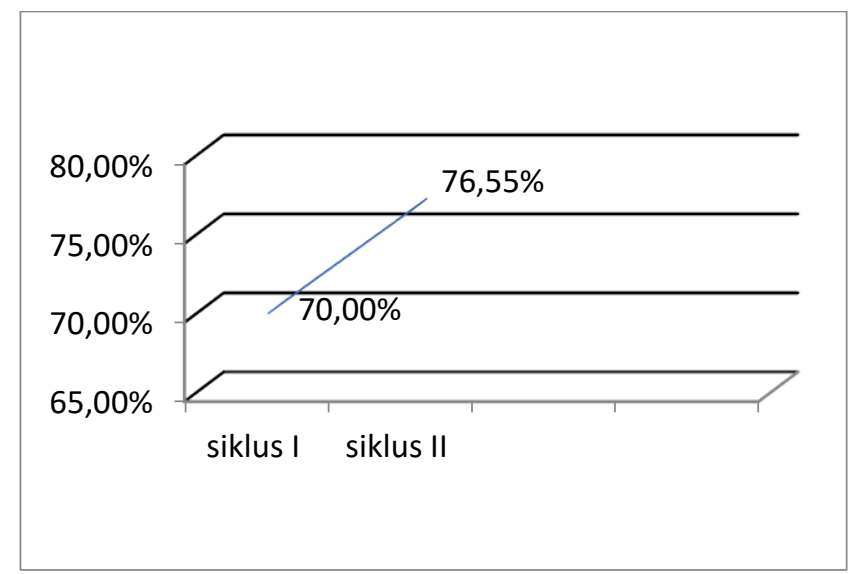

Gambar 3. Grafik Persentase Peningkatan Nilai Rata-Rata Kemampuan Berpikir Analitis

Gambar 3. menunjukkan bahwa, rata-rata nilai kemampuan berpikir analitis siswa dari pra tindakan sampai pasca tindakan mengalami peningkatan. Nilai dari salah satu siswa mengalami peningkatakn dari siklus I ke Siklus II yaitu dengna nilai 60 menjadi 90. Jadi dapat disimpulkan bahwa penerapan pendekatain saintifik dilengkapi LKS pada mata pelajaran gegorafi dapat mingkatkan kemampuan berpikir analitis siswa kelas XI IPS 2 SMA Negeri 8 Malang.

\subsection{Pembahasan Temuan Penelitian}

Penelitian yang dilakuan di SMA Negeri 8 Malang telah dilakukan dan menghasil berbagai macam temuan baik permasalahan dan juga pemecahan dari masalah terebut. Permasalahan yang paling besar dalam pembelajaran di kelas yakni kurangnya kemampuan berpikir analitis siswa. kemampuan berpikir analitis bagi siswa sangat diperlukan terutama untuk dapat memecahkan pertanyaan atau soal yang membutuhkan aspek mengingat, memahami dan menerapkan. Menggunakan kemampuan berpikir analitis dengan semaksimal 
mungkin akan membantu siswa dalam mengembangkan dan menggeneralisasikan jawaban. Selain itu menganalisis merupakan komponen penting bagi siswa untuk dapat mengolah informasi yang didapat kemudian memilah informasi tersebut menjadi bagian-bagian penting. Kemampuan berpikir analitis juga termasuk kedalam kemampuan berpikir tingkat tinggi atau high order thinking skill (HOTS). Krathwohl \& Anderson dalam Diputera (2019) menyatakan bahwa Bloom mengembangkan taksonomi dalam enam kategori domain yakni pengetahuan (knowledge), Pemahaman (comprehension), penerapan (application), analisis (analysis), sintesis (synthesis), dan evaluasi (evaluation). Kemampuan berpikir tingkat tinggi dimulai pada tingkat analisis (analysis) kemudian sintesis (synthesis) dan evaluasi (evaluation). Sedangkan pengetahuan (knowledge), Pemahaman (comprehension), penerapan (application) merupakan kemampuan berpikir tingkat rendah. Permasalahan yang terjadi di SMA Negri 8 Malang perlu mendapat tindakan karena, kemampuan berpikir analitis sangat penting bagi siswa.

Setelah melakukan observasi pembelajaran di dalam kelas XI IPS 2 didapatkan data yakni rendahnya kemampuan berpikir analitis siswa. Data tersebut didukung dengan adanya beberapa temuan lain yang merupakan faktor penyebab dari rendahnya kemampuan berpikir analitis siswa. faktor tersebut yakni pendekatan yang dilakukan di dalam kelas masih belum sesuai dengan kurikulum yang berjalan saat ini dan pemberian penugasan kepada siswa masih belum meningkatkan kemampuan berpikir analitis siswa. Kedua faktor tersebut dapat mempengaruhi kemampuan berpikir analitis siswa.

Terdapat beberapa faktor yang dapat meningkatkan kemampuan berpikir analitis siswa salah satunya yakni adalah kebiasan siswa dalam menghadapi dan menjawab soal-soal bertipe analitis. Pemberian soal analitis oleh guru kepada siswa akan membantu siswa dalam meningkatkan kemampuan berpikir analitisnya. Pertanyaan-pertanyan yang diberikan harus berdasarkan indikator dari analisis. Menurut Ross dalam Setiawati (2018) mengungkapkan beberapa indikator kemampuan analitis yakni 1) kemampuan mengidentifikasi masalah, 2) menganalisis faktor penyebab dan akibat dari suatu fenomena 3) meramalkan masalah yang akan terjadi 4) mengemukakan solusi/pemecahan maslaah dari fenomena yang tejadi dan 5) memberikan uraian analisis secara ilmiah. Memberikan siswa beberapa soal analitis akan memudahkan dan membiasakan siswa untuk mengembangkan dan menggeneralisasikan jawaban. Apabila tidak dilatih untuk menjawab soal- soal analisis, siswa akan cenderung susah untuk menjawab dan juga mengembangkan kemampuan berpikir analisisnya. Pemberian soal atau penugasan kepada siswa oleh guru harus dapat menarik dan memudahkan siswa dalam menjawab soal. Pemberian penugasan secara terstruktur akan lebih mempermudah siswa untuk mengembangkan kerangka berpikirnya dan meningkatkan kemampuan berpikir analitisnya. Pemberian penugasan harus sesuai dengan materi dan juga KI atau KD yang akan di capai.

Selain kebiasaan siswa dalam mengerjakan soal, kegiatan pembelajaran yang dilakukan didalam kelas harus dapat mendukung dalam peningkatan kemampuan berpikir analitis. setelah dilakukan observasi ditemukan bahwa guru masih menggunakan model pembelajaran konvensional atau satu arah. Dalam pembelajaran konvensional hanya menitik beratkan pada kemampuan tingkat rendah dan juga fokus pembelajaran masih berada pada guru.

Penggunaan ceramah masih sering dilakukan oleh guru, sehingga siswa hanya memperhatikan tanpa melakukan apa-apa dalam pembelajaran. kurang aktifnya siswa pada 
proses pembelajaran dapat mempengaruhi kemampuan kompetensi siswa terutama kemampuaan berpikir analitis. Berdasarkan fakta terebut, dibutuhkan tindakan yang efektif untuk dapat mengatasi permasalahan yang mempengaruhi kemampuan berpikir analitis siswa.

Menggunakan pendekatan pembelajaran didalam kelas akan membantu guru dalam menghadapi permaslahan tersebut. Pendekatan yang sesuai dengan materi pembelajaran yang di sampaikan akan membantu guru dalam penyampaian materi dan dapat mengembangkan pengetahuan siswa. Saat ini telah banyak pengembangan dari pendekatan yang dapat di terapkan oleh guru. pendekatan yang dilakukan oleh guru dapat mengikuti perkembagan kurikulum. Kurikulum yang berkembang saat ini adalah K13 atau Kurikulum 2013 dimana pendekatan pembelajaran berfokus pada siswa bukan kepada guru seperti kurikulum sebelumnya. Dalam kurikulum 2013 atau K13 terdapat banyak sekali pendekatan yang dapat diterapkan oleh guru untuk meningkatkan tingkat kognitif dan keaktifan siswa di dalam kelas. Salah satu pendekatan yang dapat diterapkan oleh guru yakni adalah pendekatan saintifik. Komara (2014) menjelaskan bahwa pada kurikulum 2013 berada pada era pedagogi modern dalam pembelajaran dengan menggunakan pendekatan ilmiah (scientific approach).

Pendekatan saintifik dapat menjadi pilihan sebagai solusi untuk mengatasi permaslahan yang dihadapi guru di SMA Negeri 8 malang. Hal tersebut dikarenakan pendekatatan saintifik mampu membuat siswa meningkatkan tingkat kognitifnya. Pendekatan saintifik memiliki makna dalam proses pembelajaran yakni siswa dapat mengeksplor kemampuannya, sedangkan guru hanya sebagai perantara atau mengarahkan siswa untuk mampu mengembangkan pengetahuannya. Hal tersebut sesuai dengan kurikuum 2013 dimana fokus pembelajaran adalah siswa bukan guru. Sintak atau tahapan-tahapan didalam pendekatan saintifik akan membantu siswa dalam melatih kemampuan pemecahan masalah secara terstruktur terutama dalam memangani soal-soal yang memerlukan kemampuan berfikir tingkat tinggi. terdapat 5 tahapan dalam pendekatan saintifk yakni mengamati, menanya, mengumpulkan informasi, mengasosiasi /mengumpulkan informasi/ meganalisis, dan mengomunikasikan.

Penelitian yang telah dilakukan pada kelas XI IPS 2 dengan subjek penelitian 34 orang siswa, SMA Negeri 8 Malang. Penelitian tersebut menunjukkan bahwa terdapat peningkatan kemampuan berpikir analitis siswa setelah diberikan tindakan berupa pendekatan saintifik dilengkapi dengan LKS. Penerapan tindakan tersebut mampu membimbing siswa dalam mengembangkan kemampuan kognitifnya terutama dalam melakukan analisis.

Pemberian tindakan dalam pembelajaran menggunakan pendekatan saintifik pada mata pelajaran geografi di kels XI IPS 2 SMA Negeri 8 Malang mampu meningkatkan kemampuan berpikir analitis siswa. Penerapan tindakan tersebut dilakuan pada materi Jenis dan Penanggulangan Bencana Alam melalui Edukasi, Karifan lokal, dan Pemanfaatan Teknologi Modern. Setelah diterapkan di dalam kelas terdapat peningkatan yang terjadi pada kemampuan berfikir analitis siswa. Peningkatan tersebut didasarkan pada indikator kemampuan berpikir analitis dimana terjadi peningkatan pada siklus I dan II. Hal tersebut menjadi bukti keberhasilan pendekatan saintifik dalam meningkatkan kemampuan berpikir analitis siswa. salah satu penelitian sebelumnya yang dilakukan oleh mukti (2015) dengan hasil yakni penggunaan pendekatan saintifik dapat meningktkan hasil belajar geografi. 
Berdasarkan hasil penelitian yang telah dilakukan menunjukkan bahwa pendekatan saintifik dilengkapi LKS dapat meningaktkan kemampuan berpikir analitis siswa kelas XI IPS 2. Pernyataan tersebut berdasarkan data yang diambil dari skor rata-rata nilai kemampuan berpikir analitis siklus I dan II. Pada siklus I skor rata-rata nilai sebesar 70 kemudian meningkat pada siklus II sebanyak 6.55 dengan skor rata-rata yakni 76.55. hasil dari tes siklus I diperoleh sebanyak 15 dari jumlah 22 siswa yang mengikuti tes atau 68.18\% siswa telah tuntas dan 7 dari jumlah 22 siswa yang mengikuti tes atau $31.82 \%$ siswa belum tuntas. Kemudian pada hasil tes siklus II menunjukkan 23 sswa dari jumlah 29 siswa yang mengikuti tes atau $79.31 \%$ telah tuntas dan 6 siswa dari jumalh 29 siswa yang mengikuti tes atau $20.68 \%$ belum tuntas. Berdasarkan hasil data tersebut maka penelitian dengan menggunakan pendekatan saintifik dilengkapi LKS dapat dihentikan karena jumlah siswa yang telah tuntas atau menguasai materi ajar telah mencapai 79.31\%. Data terebut menjadi bukti bahwa penerapan pendekatan saintifik dengna bantuan LKS dapat meningkatkan kemampuan berpiir analitis siswa. pencapaian tersebut diketahui melalui hasil evaluasi dan sejalan dengan Panduan Penyelenggaraan Pembelajaran Tuntas (mastery learning), yakni leibh dari $75 \%$ jumlah siswa telah mencapai kriteria ketuntasan minimal (KKM) dengan nilai minimum 75 sebagai ketuntasan siswa dalam penguasaan materi yang diberikan (Depdiknas, 2018).

Keberhasilan penelitian dalam meningakatkan kemampuan berpikir analitis siswa kelas XI IPS 2 pada mata pelajaran geografi terjadi karena pendekatan saintifik yang diterapkan mampu membantu siswa untuk melatih kemampuan kognitifnya. Semakin sering siswa menerima pembelajaran maupun tugas yang dapat mengasah kemampuan kognitifnya akan mempermudah siswa dalam menjawab pertanyaan yang memiliki tingkatan tinggi seperti analisis, sintesis dan evaluasi. Keberhasilan penelitian ini didapatkan bukan hanya karena penerapan pendekatan saintifik. LKS yang melengkapi pendekatan saintifik menjadi bagian yang penting dalam proses pelaksanaan tindakan di kelas dalam meningkatkan kemampuan berpikir analitis siswa.

Dalam LKS terdapat langkah-langkah pengerjaan tugas yang diberikan dan beberapa pertanyaan yang harus dijawab oleh siswa. lakah-langkah yang berada didalam LKS membantu siswa untuk dapat menjawab soal yang diberikan secara sistematis dan terstruktur. Selain itu dengan lakah-langkah tersebut mempermudah siswa dalam mengerjakan penugasan yang diberikan guru kemudian siswa dapat menjawab pertanyaan dengan lebih mudah. LKS juga mempermudah siswa dalam meningkatkan kemampuan berpikir analitisnya. Dalam LKS terdapat pertanyaan dan tugas dengan tingkat kognitif C4 atau tipe Analisis yang mampu menstimulus kemmapuan berpikir analitis siswa. Penerapan pendekatan saintifik dilengkapi dengan LKS dapat membantu siswa dalam memahami tugas yang diberikan, mengerjakan tugas dengan lebih terstruktur, memperluas pengetahuan siswa, mendorong siswa untuk bereksplorasi untuk mengolah data yang mereka dapatkan, mendapatkan banyak pegalaman dari lapangan dan fenomena yang mereka teliti, serta mampu meningkatkan kemampuan berpikir analitis.

Selain mempermudah siswa dalam mengerjakan tugas secara terstruktur dan meningkatkan kemampuan berpikir analitisnya, pendekatan sintifik yang dilengkapi LKS sangat membantu guru dalam pembelajaran dikelas. Berdsarkan hasil penelitian yang dilakukankan menunjukkan bahwa dengan menerapkan pendekatan saintifik yang di lengkapi LKS lebih unggul dari pada menggunakan metode pembelajaran yang konvensional seperti ceramah. Jika dalam metode ceramah pembelajaran akan berfokus pada guru sedangkan siswa 
hanya mendengarkan dan bertanya apabila ada yang tidak dimengerti, sedangkan menggunakan pendekatan saintifik siswa akan lebih aktif dalam mengembangkan dan menemukan informasi untuk kemudian diolah sehingga pembelajaran yang dilakukan akan lebih bermakna. Selain itu siswa akan mampu menyajikan dan mengembangkan data yang mereka dapat baik berupa tabel maupun grafik. Setelah menyajikan data, siswa dapat mengkomunikasikan hasil dari pengamatan yang telah mereka buat kepada siswa lainya sehingga dapat meningkatkan kemampuan siswa dalam melakukan komunikasi dengan audien.

Penggunaan pendekatan saintifik pada siklus I memberikan dampak yang signifikan dalam peningkatan kemampuan berpikir analitis siswa dibandingkan kegiatan pra siklus. pada saat observsi pra siklus dilakukan pembelajaran didalam kelas menggunakan metode konvensional dengan fokus pembelajaran berpusat kepada guru sedangkan siswa hanya mendengarkan. Penggunaan metode ceramah didalam kelas akan mempengaruhi proses berpikir siswa sehingga siswa dapat kesulitan dalam meningkatkan kemampuan kognitifnya terutama dalam analisis. Jika kemampuan kognitif lemah maka siswa akan kesulitan dalam menjawab dan menangani permasalahan yang diberikan. hal tersebut akan menyebabkan kesulitan siswa dalam menjawab soal dan berdampak pada nilai siswa.

Tindakan yang dilakukan pada siklus I telah menerapkan pendekatan saintifik dan dapat meningkatkan kemampuan berpikir analitis siswa, akan tetapi masih terdapat kekurangan dan beberapa permaslahaan yang muncul. Kemudian kekurangan tersebut diperbaiki pada siklus II, sehingga terdapat peningkatan yang cukup pada siklus II. Permasalahan yang dihadapi pada siklus I yakni siswa mengalami kesulitan dalam menyusun tugas yang diberikan dan mengemukakan dengan benar pendapat yang akan mereka susun, seperti: untuk pendahuluan apa saja yang harus mereka tulis, bagaimana menganalisis data, mengubungkan data dengan teori yang relevan. Berdasarkan hasil pengamatan observer, kekurangan tersebut diakibatkan oleh siswa masih belum terbiasa dalam kemampuan berpikir analitisnya.

\subsection{Pembahasan Pelaksanaan Tindakan Kelas}

Penelitian tindakan kelas yang dilakukan seharusnya dilaksanakan dalam waktu 2 minggu karena kondisi sekolah yang memiliki kegiatan diluar kegiatan pembelajaran dan terdapat hari besar sehingga libur, penelitian dilakukan dalam kurun waktu 5 minggu. Awal penelitian yakni siklus I pertemuan pertama dimulai pada hari jumat, 29 maret 2019 seharusnya penelitian dilakukan kembali pada hari senin, 1 april 2019 akan tetapi karena ada UN (Ujian Nasional) SMA sehingga penelitian siklus I pertemuan kedua dilakukan pada gri jumat, 5 april 2019. Setelah itu seharunya penelitian untuk siklus II pertemuan pertama dilaksanakan pada hari senin, 8 April 2019 akan tetapi karena masih terjadi UN (Ujian Nasional) SMA sehingga penelitian dialihkan pada hari senin, 15 April 2019 tepatnya satu minggu setelah pertemuan kedua pada siklus I. kemudian penelitian untuk siklus II pertemuan kedua dilakukan pada hari senin, 22 April 2019.

Pada siklus I guru dan siswa telah melaksanakan kegiatan sesuai dengan RPP dengan menggunakan langkah-langkah pendekatan saintifik. Akan tetapi pada siklus I masih ditemui beberapa permasalahan yang muncul dalam pembelajaran. permasalahan yang sering muncul yakni beberapa siswa melakukan kegiatan diluar konteks pembelajaran seperti berbicara dengan keras bersama teman sebangkunya, bermain hp hingga ramai pada saat temannya 
melakukan presentasi didepan kelas sehingga pembelajaran yang dilakukan menjadi kurang kondusif. Kemudian permasalahan tersebut mengalami perbaikan pada siklus II dimana pembelajaran telah berjalan dengan lebih baik. Pengembalian fokus siswa pada saat berlangsungnya presentasi kelompok dengan pemberian pertanyaan kepada siswa yang tidak meperhatikan sehingga menimbulkan efek jera dan efektif, meskipun tidak sepenuhnya. Pembelajaran yang berlangsung pada siklus II lebih kondusif dari pada siklus I.

Pemberian LKS dalam setiap siklus juga memberikan bantuan bagi siswa dan guru dalam pembelajaran. pada penelitian ini LKS memiliki peranan penting sebagai alat untuk membantu siswa dalam proses pembelajaran. Dalam LKS terapat langkah-langkah terstruktur untuk mengerjakan tugas dan menjawab soal yang diberikan oleh guru. pada siklus I tugas yang diberikan oleh guru dalam LKS yakni siswa diharuskan membuat tugas dengan format akhir yakni artikel ilmiah. Siswa diminta untuk mengamati potensi bencana yang dapat terjadi di daerah tempat tinggal mereka. Setelah mengamati siswa akan mengumpulkan data untuk mengisi tabel yang sudah disediakan didalam LKS. Tabel tersebut berisi mengenai nama daerah, potensi bencana, kriteria bencana, apakah sudah terjadi atau tidak, dan faktor penyebab. Setelah mengisi tabel tersebut siswa akan mulai menganalisis dan menjawab pertanyaan yang disediakan dalam LKS. Penyusunan jawaban tersebut sesuai dengan format artikel ilmiah yang sudah disediakan dalam LKS. Kemudian mengomunikasikan hasil dari data dan analisis yang mereka dapatkan didepan kelas.

Pada siklus II penugasan yang diberikan oleh guru didalam LKS hampir menyerupai penugasan pada siklus I akan tetapi pembahasan yang harus mereka kemukakan dan penyusunan format akhir berubah menjadi laporan tertulis. Hal tersebut akan lebih mempermudah siswa dalam mengembangkan pemikiran dan mengerjakan tugas secara lebih terstruktur. Setelah terlatih dengan tugas yang diberikan pada siklus I siswa mulai terbiasa dan dapat mengerjakan dengan baik pada siklus II. Tugas yang diberikan pada siklus II yakni siswa diminta untuk mencatat informasi yagn mereka dapat setelah melihat video mengenai bencana gempa di palu. Setelah mencatat semua informasi penting kemudian mereka memilah informasi tersebut dan menyusunnya kedalam tabel yang harus mereka buat dengan format yang sudah disediakan dalam LKS.

Setelah membuat dan mengisi tabel tersebut mereka harus mengembangkan rumusan masalah secara berkelompok. Kemudian mereka mulai melakukan analisis data yang telah mereka dapatkan kemudian menjawab rumusan masalah yang telah mereka susun. Dalam menjawab rumusan masalah tersebut siswa dapat mengaitkan dengan konsep atau teori materi yang sedang mereka pelajari. siswa dapat mendapat informasi dari mana saja dengan sumber yang falid. Setelah melakukan analisis siswa akan melakukan kegiatan peresentasi atau mengomunikasikan hasil analisis mereka kempada siswa lainnya.

Kekurangan pada penelitian saat pembelajaran berlangsung yakni, disaat siswa sedang melakukan presentasi didepan kelas, beberapa siswa akan mulai gaduh dan tidak memperhatikan kelompok yang melakukan presentasi didepan kelas. selain itu terdapat permasalah dalam kelompok dimana terdapat siswa yang tidak aktif dalam melakukan diskusi dan tidak mengerjakan bagian yang telah disepakati untuk dikerjakan dalam kelompok. Disini peran guru sangat penting untuk membimbing dan mengkontrol siswa agar tetap fokus pada pembelajaran dan mengerjakan tugas yang mereka dapat. Selain itu peran guru dalam melaksanakan pendekatan pembelajaran sangat besar, guru harus dapat memastikan bahwa 
pendekatan tersebut berjalan dengan baik, sehingga dapat berdampak pada peningkatan kemampuan berpikir analitis siswa.

Hasil penelitian ini juga didukung oleh penelitian sebelumnya. penelitian mengenai pendekatan saintiik sudah banyak dilakukan selama ini. Diantaranya yakni penelitian mengenai pendekatan saintifik yang dilakukan oleh Mukti (2015) dengan judul penelitian yakni penerapan pendekatan scientific menggunakan media video untuk meningkatkan hasil belajar geografi pserta didik pada paket C PKBM Daya Semesta Mojokerto Semester 11 2014/2015. Hasil yang diperoleh dari penelitian tersebut yakni penggunaan pendekatan saintifik dapat meningkatkan hasil belajar geografi dengan menggunakan dua siklus penelitian. Selain itu penelitian mengenai pendekatan saintifik juga pernah diakukan oleh Wuri, Orien Ratna \& Mulyanignsih Sri (2014) dengan penelitian yang berjudul penerpan pendekatan saintifik pada pembelajaran fisika materi kalor terhadap keterampilan berpikir kritis siswa kelas X SMA. Hasil yang didapat dari penelitian tersebut yakni adanya penerapan pendekatan saintifik pada pembelajaran fisika matei kalor dapat meningkatkan keterampilan berpikir siswa kelas X SMA dengan menggunakan rancangan one group pretest-posttest. Berdasarkan kedua hasil penelitian tersebut pendekatan sintifik telah mampu mengatasi berbagaimacam permsalahan yang tejadi didalam kelas. selain itu dalam penelitian ini, membuktikan bahwa pendekatan saintifik dapat meningkatkan kemampuan kognitif siswa ykani dalam tingkat analisis.

\section{Simpulan}

Berdasarkan hasil penelitian dapat diperoleh kesimpulan sebagai berikut: (1) Penggunaan Pendekatan Saintifik dilengakapi LKS dalam meningkatkan kemampuan berpikir analitis siswa kelas XI IPS 2 SMA Negeri 8 malang tahun ajaran 2018/2019 mengalami peningkatan. Data yang diperoleh yakni sebelum diterapkannya pendekatan saintifik dilengkapi LKS dalam pembelajaran geografi, diperoleh sebanyak 22 siswa belum tuntas sedangkan 13 siswa telah tuntas dari toal 35 siswa. namun setelah dilakukan tindakan dengan menerapkan pendekatan saintifik pada mata pelajaran geografi di kelas XI IPS 2, terbukti efektif dalam menangani permasalahan kurangnya kemampuan berpikir analitis siswa. (2) Penerapan pendekatan saintifik juga membantu guru dalam melakukan pembelajaran didalam kelas dengan lebih terstruktur. (3) Pendekatan saintifik efektif mampu meningkatkan kemampuan berpikir anatis siswa yang dapat ditinjau dari hasil Pembelajaran Tuntas (mastery learning). Keberhasilan penelitian ini disebabkan oleh penerapan pendekatan saintifik dilengkapi dengan LKS sehingga siswa dapat dengan mudah mengerjakan tugas yang diberikan dan melatih siswa untuk dapat terbiasa menggunakan kemampuan berpikir analitisnya. (4) Keberhasilan penelitian ini dapat dilihat dari hasil kemampuan berpiir analitis siswa pada siklus I dan II diperoleh data bahwa hasil dari test kemampuan berpikir analitis siswa meningkat. Hasil tes siklus I diperoleh sebanyak 15 dari jumlah 22 siswa yang mengikuti tes atau $68.18 \%$ siswa telah tuntas. Kemudian pada hasil tes siklus II menunjukkan 23 sswa dari jumlah 29 siswa yang mengikuti tes atau 79.31\% telah tuntas. Dengan adanya peningkatan yang terjadi pada siswa yang telah mencapai $79.31 \%$ siswa telah tuntas dan melebihi $75 \%$ indikator keberhasilan maka dinyatakan bahwa perbaikan pembelajaran ini telah berhasil.

Berdasarkan kesimpulan hasil penelitian mengenai Penerapan Pendekatan Saintifik Dilengkapi LKS untuk Meningkatkan Kemampuan Berpikir Analitis Siswa Kelas XI IPS 2 SMA Negeri 8 Malang, maka penulis dapat mengemukakan beberapa saran yang sekiranya dapat dijadikan masukan/ pertimbangan: (1) Bagi guru, sebaiknya setelah mengetahui dampak yang ditimbulkan dari penlitian yang di lakukan di kelas XI IPS 2, pendekatan saintifik dilengkapi 
LKS dapat menjadi alternatif bagi guru dalam melakukan pembelajaran karena pendekatan saintifik dilengkapai dengan LKS dapat meningkatkan kemampuan berpikir analitis siswa. (2) Peneliti selanjutnya diharapkan dapat mempergunakan penelitian ini sebagai acuan untuk menggunakan pendekatan saintifik ataupun LKS untuk dapat meningkatkan tingkat kognitif siswa yang lainya.

\section{Daftar Rujukan}

Abdul, majid. (2013). Strategi Pembelajaran. Bandung: Remaja Rosdakarya.

Ali, Jumalia, Rizal, Yusmet, \& Lukman, Nurhayati. (2012). Strategi Pembelajaran Aktif The Power of Two dan Kemampuan Komunikasi Matematika. Jurnal Pendidikan Matematika, 1(1). Dari http://ejournal.unp.ac.id.

Asmirani Urai, Putra Amali, \& Asrizal. (2013). Pengaruh LKS Berbasis Sains Teknologi Masyarakat Terhadap Kompetensi Siswa Dalam Pembelajaran IPA Fisika di Kelas VIII SMPN 1 Kubung Kabupaten Solok 01(8590). Dari http://ejournal.unp.ac.id.

Arafah Sherlly ferdiana, Ridlo Saiful, \& Priyono Bambang. (2012). Pengembangan LKS Berbasis Berpikir Kritis Pada Materi Animalia, Jurnal Pendidikan Biologi, 1(1). Dari http://Jorunal.unnes.ac.id.

Arikunto Suharsimi. (2013). Prosedur Penelitian Suatu Pendekatan Praktik. Jakarta: PT. Rineka Cipta.

Aryani Farida, \& Hiltrimartin Cecil. (2011). Pengembangan LKS Untuk Metode Penemuan Terbimbing Pada Pembelajaran Matematika Kelas VIII di SMP Negeri 18 Palembang, Jurnal Pendidikan Matematika, 5(2). Dari http://ejurnal2.unsri.ac.id.

Awaliyah Gumanti. (2018). Siswa Mengaku Soal HOTS Belum Disosialisasikan di Sekolah. (Berita Online) (https://republika.co.id/berita/pendidikan/eduaction/18/10/28/phalvq428-siswa-mengaku-soalhots-belum-disosialisasikan-di-sekolah), diakses tanggal 30 Oktober 2018.

Bintar, Ni luh Gede Riwan Putri, Sudiana, I Nyoman, \& Putrayasa, Ida Bagus. (2014). Pembelajaran Bahasa Indonesia Berdasarkan Pendekatan Saintifik (Problem Based Learning), Vol.03. Dari https://media.neliti.com/media/publications/206959-pembelajaran-bahasa-indonesiaberdasarka.pdf)

Darmodjo Hendro dan Jenny R.E. Kaligis. (1993). Pendidikan IPA II. Jakarta: Depdikbud (Proyek Pembinaan Tenaga Kependidikan).

Daryanto. (2014). Pendekatan Pembelajaran Saintifik Kurikulum 2013. Yogyakarta: Penerbit Gava Media.

Dawati Henri Nelista Mei, Krtanto Puguh, \& Sugiharto Bowo. (2015). Perbedaan Kemampuan Berpikir Analitis Pada Model Problem Based Learning Disertai Mind Map Dengan Kelas Konvensional Pada Siswa Kelas X Ipa Sma Al Islam 1 Surakartatahun Pelajaran 2013/ 2014. Jurnal Pendidikan Biologi 7(2). Dari https://eprints.uns.ac.id/17000/.

Diputera Artha Mahindra. (2019). Kemampuan Berpikir Tingkat Tinggi (HOTS). Journal Reseapedia 1(1). Dari https://www.academia.edu/38340925/Kemampuan_Berpikir_Tingkat_Tinggi_HOTS_

Hoaeti Eli, Widjajanti LFX, Endang \& Padmaningrum, Regina tutik. (2009). Pengembangan Lembar Kerja Siswa (LKS) Mata Pelajaran Sains Kimia Untuk SMP 10(1). Dari http://staff.uny.ac.id/sites/default/files/pengabdian/das-salirawati-msi-dr/19penyusunnan-dan-kegunaan-lks.pdf.

Jurnal Penabur. (2012). Jurnal Pendidikan Penabur (JPP). Jakarta Barat: Badan Pendidikan Kristen Penabur (BPK Penabur).

Khanifatus. (2013). Pembelajaran Inovatif (Strategi Mengelola Kelas Secara Efektif dan Menyenangkan). Jogjakarta: AR-RUZZ MEDIA.

Kusaeri. (2014). Acuan \& Teknik Penilaian Proses \& Hasil Belajar Dalam Kurikulum 2013. Yogyakarta: Ar-Ruzz Media.

Komara, Endang. (2014). Belajar dan Pembelajaran Interaktif. Bandung: PT. Refika Aditama.

Laksono, Endang W., Rohaeti, Eli, Suyata, \& Irwanto. (2017). Instrumen Penilaian Kemampuan Berpikir analitis dan Keterampilan Proses Sains Kimia. Jurnal Kependidikan 1(1). Dari http://ejournal.upi.edu).

Marjan Johari, Arnyana, I.B. Putu, \& Setiawan Nyoman. (2014). Pengaruh Pembelajaran Pendekatan Saintifik Terhadap Hasil Belajar Biologi dan Keterampilan Proses Sains Siswa MA Mu'allimat NW Pancor Selong 
Kabupaten Lombok Timur Nusa Tenggara Barat, Vol.04. dari http://119.252.161.254/ejournal/index.php/jurnal_ipa/article/view/1316.

Megawati, Yolanda Dian Nur, Sari, Annisa Ratna. (2012). Model Pembelajaran Kooperatif Tipe Team Assisted Individualization (TAI) dalam Meningkatkan Keaktifan Siswa dan Hasil Belajar Akuntansi Siswa Kelas XI IPS 1 SMA Negeri 1 Banjarnegara Tahun Ajaran 2011/2012, Jurnal Pendidikan Akuntansi Indonesia 1(1). Dari http://journal.uny.ac.id.

M.Taleb, Hanam \& Chadwick Clifton. (2016). Enhancing Student Critical And Analytical Thinking Skills at a Higher Education Level in Developing Countries: Case Study of the British University in Dubai: $A n$ International Journal, 6(01),08. Dari http://www.wjeis.org/FileUpload/ds217232/File/8.hanan_m._taleb.pdf.

Murtianto Hendro. (2008). Modul Belajar Geografi. Universitas Pendidikan Indonesia. (Online), (https://s3.amazonaws.com/academia.edu.documents.com), diakses 21 Januari 2019.

Nusyamsuddin, dkk. (2013). Pembelajaran Berbasis Kompetensi dengan Pendekatan Saintifik. Jakarta: Kemendikbud RI.

Puspita, Ratna. (2018). Keterampilan Berpikir Tinggi Bukan Hanya Saat Ujian, Tetapi Juga Proses Pembelajaran. (Berita Online) (https://www.republika.co.id/berita/pendidikan/eduaction/18/04/15/p78hm7428sebagian-besar-siswa-masih-berpikir-level-rendah). diakses tanggal 18 Oktober 2018.

Puspita Ratna. (2018). Keluhan Siswa Tunjukkan Ketimpangan Pembelajaran \& Evaluasi. (Berita Online) (https://republika.co.id/berita/pendidikan/eduaction/18/04/15/p78f8o428-keluhan-siswatunjukkan-ketimpangan-pembelajaran-evaluasi), diakses tanggal 30 Oktober 2018.

Ratumanan. (2015). Inovasi Pembelajaran (Mengembangkan Kompetensi Peserta Didik Secara Optimal). Yogyakarta: Penerbit Ombak.

K. Robbins, Joanne. (2011). Problem Solving, Reasoning, and Analytical Thinking in a Classroom Environment 12(1). Dari http:// psycnet.apa.org.

Sablonniere Roxane de la, M. Taylor Donald \& Sadykova Nazgul. (2009). Challenges of Applying a StudentCentered Approach to Learning in the Context of Education in Kyrgyzstan, International Journal of Education Development EDEV-1142 (07). Dari http://www.mapageweb.umontreal.ca.

Sani, Abdullah Ridwan. (2015). Pembelajaran saintifik untuk implementasi kurikulum 2013. Jakarta: PT.Bumi Aksara.

Salirawati Das. (2006). Penyusunan dan Kegunaan LKS Dalam Proses Pembelajaran, (Online), staffnew.uny.ac.id, diakses tanggal 10 November 2018.

Setiawati Rokhis. (2018). Peningkatan Kemampuan Analisis Transaksi Dalam Menyusun Jurnal Dengan Model Problem Based Learning Melalui Pengamatan BT/BK, Inopendas Jurnal Ilmiah Kependidikan 1(1). Dari http://jurnal.umk.ac.id.

Saregar, Antomi. (2016). Pembelajaran Pengantar Fisika Kuantum dengan Memanfaatkan Media Phet Simulation dan LKM Melalui Pendekatan Saintifik: Dampak Pada Minat dan Penguasaan Konsep Mahasiswa. Jurnal Ilmiah Pendidikan Fisika AL-BiRuNi 05(1) (53-60). Dari http://ejournal.radenintan.ac.id/index.php/al-biruni/article/view/105.

Soleh Muh. (2017). Perencanaan Pembelajaran Mata Pelajaran Geografi Tingkat SMA dalam Konteks KTSP 04(02). Dari http:// journal.unnes.ac.id.

Sudarisman, Suciati. (2015). Memahami Hakikat dan Karakteristik Pembelajaran Biologi Dalam Upaya Menajwab Tantangan Abad 21 Serta Optimalisasi Implementasi Kurikulum 2013, Jurnal Florea 2(1). Dari http:// e-journal.unipma.ac.id.

Tandulling Edy. (2012). Pengembangan Instrumen untuk Mengukur Kemampuan Komunikasi Matematika, Pemahaman Matematika, dan Self- Regulated Learning siswa dalam Pembelajaran Matematika di Sekolah Menengah Atas. Jurnal Penelitian Pendidikan 13(1). Dari http://academia.edu

Trianto. (2009). Mendesain Model Pembelajaran Inovatif-Progresif. Jakarta: Kencana Predana Media Grup.

Turkkahraman Mimar. (2012). The Role of Educarion in the Societal Develompent. Journal of educational and instructional studies in the world. Vol.02 Issue.04 ISSN: 2146-746. Dari http://www.wjeis.org/FileUpload/ds217232/File/04.turkkahraman.pdf. 
Jurnal Integrasi dan Harmoni Inovatif Ilmu-Ilmu Sosial (JIHI3S), 1(3), 2021, 336-349

Wareza Monica. (25 Desember 2018). Ini Korban Jiwa dan Kerugian dari 3 Bencana Alam RI di 2018 (CNBC INDONESIA) (Online) https://www.cnbcindonesia.com/news/20181225141956-4-47867/ini-korbanjiwa-dan-kerugian-dari-3-bencana-alam-ri-di-2018, dikses tanggal 30 Januari 2019

Wijayati, Eni Cahya, Sudana, I Nyoman, \& Sumarmi. (2016). Kesulitan- Kesulitan Dalam Implementasi Kurikulum Mata Pelajaran IPS SMP. Jurnal Pendidikan: Teori, Penelitian, dan Pengembangan, 1(11). Dari http://journal.um.ac.id/index.php/jptpp/article/view/8132).

Widjajanti Endang. (2008). Kualitas Lembar Kerja Siswa, (Online), staffnew.uny.ac.id, diakses tanggal 10 November 2018.

Winarso Widodo. (2014). Membangun Kemampuan Berfikir Matematika Tingkat Tinggi Melalui Pendekatan Induktif, Deduktif dan Induktif- Deduktif dalam Pembelajaran Matematika, EduMa 3(2). Dari http://syekhnurjati.ac.id

Yuianti Evi. (2014). Validitas LKS Pengamatan Berdasarkan Pendekatan Saintifik Pada Pokok Bahasan Angiospremae BioEdu 3(3). Dari jurnalmahasiswa.unesa.ac.id 